\title{
ASSESSMENT OF REPRODUCTIVE TOXICITY AND GONADOTOXIC POTENTIAL OF N-METHYL-2-PYRROLIDONE IN MALE RATS
}

\author{
KRYSTYNA SITAREK ${ }^{1}$ and JAN STETKIEWICZ ${ }^{2}$ \\ ${ }^{1}$ Department of Toxicology and Carcinogenesis \\ ${ }^{2}$ Department of Pathomorphology, \\ Nofer Institute of Occupational Medicine \\ Łódź, Poland
}

\begin{abstract}
Objectives: N-methyl-2-pyrrolidone (NMP) is a solvent used in petrochemical, electric and electronic industries, and in the production of paint removers, pesticides and veterinary drugs. The substance exhibits slight acute toxicity, and moderate irritant, embryotoxic and teratogenic effects. The aim of the study was to assess NMP reproductive toxicity and gonadotoxicity in male rats. Material and Methods: The animals were exposed per os to NMP at daily doses of 0, 100, 300 and $1000 \mathrm{mg} / \mathrm{kg}$. After 10 weeks of exposure, each male was mated with nonexposed female, then all the males were autopsied, and epididymis and testis were fixed for pathomorphological examination. Viability and development of offspring was observed to 28 days postbirth. Results: NMP at $1000 \mathrm{mg} / \mathrm{kg}$ was found to produce male infertility and extensive damage to the seminiferous epithelium in the seminal tubules of the testis. When administered at $100 \mathrm{mg} / \mathrm{kg}$ or $300 \mathrm{mg} / \mathrm{kg}$, it did not significantly affect fertility or spermatogenesis. NMP exposure at $100 \mathrm{mg} / \mathrm{kg}$ did not influence either the viability or the development of their offspring in the first month of life, while exposure at $300 \mathrm{mg} / \mathrm{kg}$ resulted in a significantly lower viability of the offspring in the first four days of life. Conclusion: This study has demonstrated that sub-chronic exposure of male rats to NMP at $1000 \mathrm{mg} / \mathrm{kg} /$ day produces gonadotoxic effect and brings about infertility. Administration at lower doses of 100 and $300 \mathrm{mg} / \mathrm{kg}$ did not impair male fertility, but only the lowest dose of $100 \mathrm{mg} / \mathrm{kg}$ was found to have no influence on the prenatal development of the progeny.
\end{abstract}

Key words:

N-methyl-2-pyrrolidone, NMP, Gonadotoxicity, Fertility, Rats

\section{INTRODUCTION}

$\mathrm{N}$-methyl-2-pyrrolidone (NMP) is an organic solvent easily miscible with water. It is used as a solvent or remover for paints or resins, as a vehicle for pigments, an intermediate product in the chemical industry, crude oil processing, and to produce varnish or polyvinyl chloride. NMP has also numerous applications in the electric and electronic industries, and in the manufacture of pesticides and veterinary drugs. Owing to its characteristics, it is used as a replacement for methyl chloride [1].
Considering good solubility both in polar and non-polar solvents, NMP may be expected to easily permeate the biological membranes and the skin. This conjecture is confirmed by experiments intended to test NMP's ability to permeate the skin of humans and experimental animals [2,3]. NMP is also easily absorbed in the respiratory and alimentary tracts of experimental animals. Values of median lethal doses $\mathrm{LD}_{50}$ following intragastric administration to rats, mice, guinea pigs and rabbits range from 3900 to $7700 \mathrm{mg} / \mathrm{kg}$ b.w. [4], while median lethal doses

Received: November 19, 2007. Accepted: January 21, 2008.

The study was supported by the State Committee for Scientific Research, Poland (Grant No.618/PO5/2003/24) and the Nofer Institute of Occupational Medicine scientific research program for 2003-2006 (Project IMP 1.9).

Address reprint requests to K. Sitarek, PhD, Department of Toxicology and Carcinogenesis, Nofer Institute of Occupational Medicine, św. Teresy 8, 91-348 Łódź, Poland (e-mail: ksitarek@imp.lodz.pl). 
after NMP application to the skin of rats or rabbits range from 4000 to $10000 \mathrm{mg} / \mathrm{kg}$ b.w. [5].

Irregular breathing, ataxia and arousal followed by coma were noted after each daily exposure in rats exposed by inhalation to 100,500 and $1000 \mathrm{mg} / \mathrm{m}^{3} \mathrm{NMP}$ aerosol $6 \mathrm{~h} /$ day, 5 days/week for 28 days. After 30 to 45 min since the termination of exposure at the two lower doses, the symptoms disappeared completely. In the animals exposed to the highest concentration of $1000 \mathrm{mg} / \mathrm{m}^{3}$, the symptoms persisted for longer time, and several cases of death were also recorded. Histopathological examinations of the dead animals revealed inflammatory foci in the lung, bone marrow hyperplasia, and lymphatic tissue atrophy in the spleen and thymus. In the survivors, the changes disappeared after about 2 weeks since the termination of exposure. No significant toxic effects of NMP were noted in the animals exposed to the lower concentrations of $500 \mathrm{mg} / \mathrm{m}^{3}$ and $100 \mathrm{mg} / \mathrm{m}^{3}$ [6]. The results of experimental studies indicate that NMP at doses causing no or mild maternal toxicity affects prenatal and postnatal development of animals [7-9].

\section{MATERIAL AND METHODS}

The present study was performed in conformity with the current Polish and EU regulations (Official Gazette No. 11 of August 21, 1997, item 724, Act on Protection of Animals, Section 9: Experimental Procedures with the Use of Animals). The research team has obtained from the Biomedical Ethics Committee, Łódź, the consent to proceed with the tests on animals (Document No. $\mathrm{L} / \mathrm{BD} / 140$ of July 29, 2002).

\section{Test substance}

N-methyl-2-pyrrolidone, CAS Number 872-50-4, analytical grade, from Sigma Co. was used in the study.

\section{Experimental animals, exposure conditions}

The tests were performed on male and female outbred Imp:WIST rats from the Nofer Institute's animal breeding farm. Before the testing, the animals had been subjected to a 5-day adaptation: $12 \mathrm{~h} / 12 \mathrm{~h}$ light/dark cycle, ambient temperature $22^{\circ} \mathrm{C} \pm 2^{\circ} \mathrm{C}$, and relative humidity $45-55 \%$. The animals were maintained on commercial rat pelleted chow (Fodder Factory, Motycz, Poland) and tap water accessible ad libitum. At the onset of exposure, the males were 7 weeks old.

Male rats assigned at random to one of four groups were exposed by gavage to NMP water solutions at 100, 300 or $1000 \mathrm{mg} / \mathrm{kg}$ b.w. (2.5\% to $25 \% \mathrm{LD}_{50}$ per os) 5 days $/$ week for 10 weeks before mating and for 1 week during mating. The controls received by gavage equivalent quantities of tap water. Each time, the animal received $0.5 \mathrm{ml}$ per $100 \mathrm{~g}$ b.w. Body weight, and fodder and water intake in all the groups were recorded once a week.

\section{Male fertility testing}

After termination of 10 weeks' exposure, each male rat was mated for a period of 1 week with a virgin, sexually adult (12-week-old) non-exposed female. The same pairs of animals were mated at a 1:1 ratio in the control group and the 100 and $300 \mathrm{mg} / \mathrm{kg}$ groups, and 1:2 ratio in the $1000 \mathrm{mg} / \mathrm{kg}$ group. Vaginal smears were collected each day from the mated females. The day on which sperms were found was assumed to be the day 0 of pregnancy, and the fertilized females were transferred to single cages. Their behaviour, body weight gain in pregnancy, and daily fodder and water intakes were monitored.

After the mating period was over, the control and NMPexposed males were autopsied. The animals were decapitated under light ether anesthesia, and integral indices of toxicity, including body weight on the day of dissection, macroscopic assay of the internal organs, hematocrit value, and absolute and relative weight of the internal organs were measured. The testis and epididymis were fixed and secured for pathomorphological examination.

In NMP-exposed and control rats, the assessment of early postnatal development of the offspring was continued until the end of the lactation period i.e. until the offspring was 28 days old. Maternal behaviours such as the construction of hatching nest, signs of neonate suckling, feeding and nursing were assessed. After the delivery, the number of live and dead neonates was assessed in each litter. During the first $24 \mathrm{~h}$ of life, the neonates were examined for possible, macroscopically evident, congenital malformations. On day 4, the number of animals in each litter was 
reduced to 8 animals (4 females and 4 males). At predetermined days of the offspring life (days 1, 4, 7, 14, 21), body weight was assessed, and the signs of physical development of the pups: the day of pinna detachment, incisor eruption and lid slit opening were recorded.

\section{Gonadotoxicity testing}

The testis and epididymis of the control and NMP-exposed males were removed during the dissection for pathomorphological examination. One testis and one epididymis of each animal were preserved in Bouin's solution, while the other ones were preserved in $10 \%$ formaldehyde phosphate solution. The 4 to $6 \mu \mathrm{m}$ thick microscopic specimens (standard paraffin technique) were stained with haematoxylin and eosin. Additional specimens were stained with Schiff (PAS) stain with haematoxylin.

The authors of the fundamental reports on the assessment of individual stages of spermatogenesis emphasize that a detailed assessment of the seminiferous epithelium is possible in semi-thin sections prepared from the tissue embedded in methacrylate or a synthetic resin $[10,11,12]$. Paraffin techniques and PAS/hematoxylin staining are extensively used to assess the developmental stages of seminiferous epithelium. For quantitative and qualitative assessment of these stages, the principles presented by Hess were used [11].

The pre-assessment of slides has led us to a decision that it would be advisable to aggregate the results from stages I -V, VI-VIII, IX-XIV. This method was employed in our study to evaluate the findings. Individual stages of spermatogenesis of seminiferous epithelium were assessed in 80 to 100 cross-sections of testicular tubules. According to the key provided by Hess [11], the intervals are characterized by:

a) stage I-VIII - presence of two spermatid types (oval and elongate),

b) stage I-V - absence of elongate spermatids near the lumen of the tubules and a layer of about 8 to 10 spermatids present in the epithelial cross-section,

c) stage IV and X-XIV - presence of mitotic figures,

d) stage VI-VIII - presence of elongate spermatids in the vicinity of the tubular lumen.

\section{Statistical analysis}

For the statistical evaluation of results, one-way analysis of variance and Dunnett's test, or Kruskal-Wallis analysis of variance followed by non-parametric test [13] were used where appropriate. Fisher exact test [13] was used to analyze the frequency of the qualitative characteristics. The effects of NMP on body weight and chow and water intake were assessed by multiple comparison test [14]. In all the statistical analyses, the difference between the compared variables was assumed to be statistically significant at $\mathrm{p}<0.05$.

\section{RESULTS}

\section{Assessment of fertility and N-methyl-2-pyrrolidone gonadotoxicity in male rats}

Throughout the experiment, no significant differences were noted in the behaviour of the control animals and those exposed to NMP at $100 \mathrm{mg} / \mathrm{kg} /$ day or $300 \mathrm{mg} / \mathrm{kg} /$ day. After 4 to 5 weeks of exposure, the males exposed to the highest dose were slightly less mobile, dejected, squealed when handled by the experimenter, and they passed deep yellow urine. Body weight gain of the males exposed to NMP at all doses (100-1000 mg/kg/day) was significantly lower than that of the controls (Fig. 1). During the first weeks of exposure to 100 and $300 \mathrm{mg} / \mathrm{kg} /$ day, the daily food intake was $8-12 \%$ higher than among the controls. Later on, it did not differ between the exposed and control

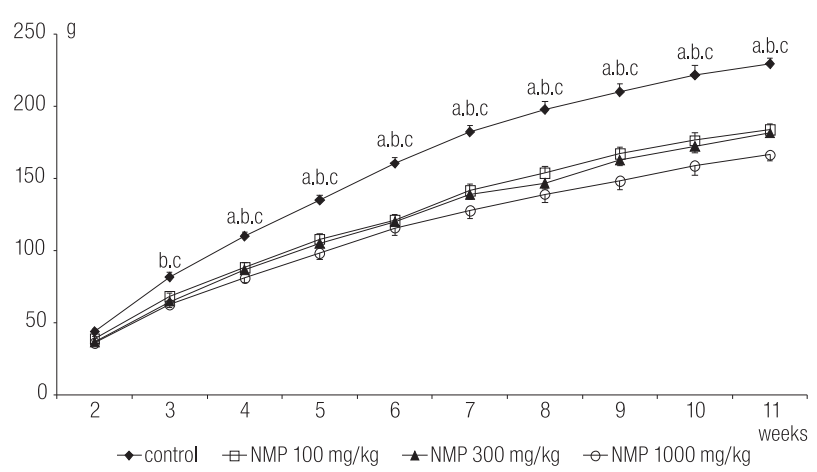

Fig. 1. Body weight gain in male rats exposed to N-methyl-2-pyrrolidone for 11 weeks. The figure displays means \pm SE from $22-24$ males in each group. Significantly different ( $\mathrm{p}<0.05$ ): (a) control vs. $100 \mathrm{mg} / \mathrm{kg}$; (b) control vs. $300 \mathrm{mg} / \mathrm{kg}$; (c) control vs. $1000 \mathrm{mg} / \mathrm{kg}$. 
animals. The daily water intake in the $100 \mathrm{mg} / \mathrm{kg}$ group was $8-25 \%$ lower than in the controls throughout the exposure, while in the $300 \mathrm{mg} / \mathrm{kg}$ group, it was about $12 \div 16 \%$ lower only during week 6,9 and 10 of exposure.

Hematocrit value determined on the day of dissection was significantly higher in the $1000 \mathrm{mg} / \mathrm{kg}$ group than in the controls (44.9 vs. 42.3). In the two other exposed groups, haematocrit level did not differ from that recorded for the controls.

The toxic effect of NMP was also manifested by significant changes in the weight of the internal organs of the exposed animals (Table 1). The absolute and relative weights of the testis and epididymis in the $1000 \mathrm{mg} / \mathrm{kg}$ group were significantly lower than those in the control, while the absolute and relative weights of the thyroid gland and pituitary were higher than in the control animals. In rats exposed to lower NMP doses, the weight of epididymis was higher than among the non-exposed rats. On the other hand, the absolute and relative weights of the pituitary, thyroid gland, adrenals, spleen, and testis in the animals exposed to NMP at 100 and $300 \mathrm{mg} / \mathrm{kg}$ did not differ significantly from the weights found for the controls. The relative weight of the

Table 1. Organ weight in male rats receiving N-methyl-2 pyrrolidone for 11 weeks

\begin{tabular}{|c|c|c|c|c|}
\hline \multirow{2}{*}{ Organ } & \multicolumn{4}{|c|}{ NMP dose (mg/kg b.w.) } \\
\hline & 0 & 100 & 300 & 1000 \\
\hline $\begin{array}{l}\text { Testis } \\
\mathrm{g} \\
\mathrm{g} \%\end{array}$ & $\begin{array}{c}23 \\
2.97 \pm 0.19 \\
0.79 \pm 0.08\end{array}$ & $\begin{array}{c}24 \\
2.97 \pm 0.33 \\
0.82 \pm 0.1\end{array}$ & $\begin{array}{c}23 \\
3.0 \pm 0.42 \\
0.83 \pm 0.15\end{array}$ & $\begin{array}{c}22 \\
1.85 \pm 0.64^{\mathrm{a}} \\
0.61 \pm 0.23^{\mathrm{a}}\end{array}$ \\
\hline $\begin{array}{l}\text { Epididymis } \\
\text { g } \\
\mathrm{g} \%\end{array}$ & $\begin{array}{c}23 \\
0.49 \pm 0.07 \\
0.13 \pm 0.02\end{array}$ & $\begin{array}{c}24 \\
0.53 \pm 0.05^{\mathrm{a}} \\
0.15^{ \pm} 0.02^{\mathrm{a}}\end{array}$ & $\begin{array}{c}23 \\
0.54 \pm 0.05^{\mathrm{a}} \\
0.15 \pm 0.02^{\mathrm{a}}\end{array}$ & $\begin{array}{c}22 \\
0.35 \pm 0.08^{\mathrm{a}} \\
0.12 \pm 0.03^{\mathrm{a}}\end{array}$ \\
\hline $\begin{array}{l}\text { Brain } \\
\qquad \mathrm{g} \\
\mathrm{g} \%\end{array}$ & $\begin{array}{c}23 \\
1.62 \pm 0.12 \\
0.44 \pm 0.05\end{array}$ & $\begin{array}{c}24 \\
1.85 \pm 0.06^{\mathrm{a}} \\
0.51 \pm 0.04^{\mathrm{a}}\end{array}$ & $\begin{array}{c}24 \\
1.82 \pm 0.06^{\mathrm{a}} \\
0.50 \pm 0.04^{\mathrm{a}}\end{array}$ & $\begin{array}{c}22 \\
1.53 \pm 0.12^{\mathrm{a}} \\
0.50 \pm 0.04^{\mathrm{a}}\end{array}$ \\
\hline $\begin{array}{l}\text { Liver } \\
\qquad \mathrm{g} \\
\mathrm{g} \%\end{array}$ & $\begin{array}{c}23 \\
12.7 \pm 1.82 \\
3.44 \pm 0.23\end{array}$ & $\begin{array}{c}24 \\
12.93 \pm 1.34 \\
3.55 \pm 0.19\end{array}$ & $\begin{array}{c}24 \\
13.13 \pm 1.5 \\
3.62 \pm 0.22^{\mathrm{a}}\end{array}$ & $\begin{array}{c}22 \\
11.61 \pm 1.66 \\
3.74 \pm 0.33^{\mathrm{a}}\end{array}$ \\
\hline $\begin{array}{l}\text { Spleen } \\
\qquad \mathrm{g} \\
\mathrm{g} \%\end{array}$ & $\begin{array}{c}23 \\
0.76 \pm 0.32 \\
0.21 \pm 0.11\end{array}$ & $\begin{array}{c}24 \\
0.58 \pm 0.13 \\
0.19 \pm 0.04\end{array}$ & $\begin{array}{c}24 \\
0.63 \pm 0.17 \\
0.17 \pm 0.04\end{array}$ & $\begin{array}{c}22 \\
0.55 \pm 0.17^{\mathrm{a}} \\
0.18 \pm 0.06\end{array}$ \\
\hline $\begin{array}{l}\text { Kidney } \\
\text { g } \\
\mathrm{g} \%\end{array}$ & $\begin{array}{c}23 \\
2.43 \pm 0.23 \\
0.66 \pm 0.09\end{array}$ & $\begin{array}{c}24 \\
2.33 \pm 0.2^{\mathrm{a}} \\
0.64^{ \pm} 0.05\end{array}$ & $\begin{array}{c}24 \\
2.44 \pm 0.24 \\
0.67 \pm 0.04\end{array}$ & $\begin{array}{c}22 \\
2.17 \pm 0.21^{\mathrm{a}} \\
0.70 \pm 0.06^{\mathrm{a}}\end{array}$ \\
\hline $\begin{array}{l}\text { Adrenals } \\
\text { mg } \\
\mathrm{mg} \%\end{array}$ & $\begin{array}{c}23 \\
51.57 \pm 12.59 \\
14.2 \pm 4.21\end{array}$ & $\begin{array}{c}24 \\
47.96 \pm 4.46 \\
13.26 \pm 1.76\end{array}$ & $\begin{array}{c}24 \\
48.3 \pm 5.97 \\
13.37 \pm 1.67\end{array}$ & $\begin{array}{c}22 \\
50.81 \pm 5.85 \\
16.51 \pm 2.22^{\mathrm{a}}\end{array}$ \\
\hline $\begin{array}{c}\text { Thyroid } \\
\text { mg } \\
\mathrm{mg} \%\end{array}$ & $\begin{array}{c}22 \\
15.43 \pm 3.45 \\
4.26 \pm 1.19\end{array}$ & $\begin{array}{c}24 \\
15.6 \pm 1.89 \\
4.31 \pm 0.66\end{array}$ & $\begin{array}{c}24 \\
15.52 \pm 2.16 \\
4.29 \pm 0.56\end{array}$ & $\begin{array}{c}22 \\
18.81 \pm 3.76 \pm^{\mathrm{a}} \\
6.09^{ \pm} 1.29^{\mathrm{a}}\end{array}$ \\
\hline $\begin{array}{c}\text { Pituitary } \\
\text { mg } \\
\mathrm{mg} \%\end{array}$ & $\begin{array}{c}22 \\
9.55 \pm 2.54 \\
2.63 \pm 0.75\end{array}$ & $\begin{array}{c}24 \\
9.56 \pm 0.74 \\
2.63 \pm 0.21\end{array}$ & $\begin{array}{c}24 \\
9.45 \pm 0.91 \\
2.61 \pm 0.24\end{array}$ & $\begin{array}{c}22 \\
10.41 \pm 2.34 \\
3.37 \pm 0.71^{\mathrm{a}}\end{array}$ \\
\hline $\begin{array}{l}\text { Body weight } \\
\text { g }\end{array}$ & $\begin{array}{c}23 \\
368.13 \pm 36.65\end{array}$ & $\begin{array}{c}24 \\
364.63 \pm 31.58\end{array}$ & $\begin{array}{c}24 \\
362.25 \pm 26.78\end{array}$ & $\begin{array}{c}22 \\
310.50 \pm 33.40^{a}\end{array}$ \\
\hline
\end{tabular}

Mean \pm SD from 22-24 males in each group.

$\mathrm{g} \%$ and $\mathrm{mg} \%$ - relative weight of organ (per $100 \mathrm{~g}$ b.w.).

${ }^{a}$ significantly different $(\mathrm{p}<0.05)$ from the control values. 
liver, adrenals, kidney and brain in the animals of the 1000 $\mathrm{mg} / \mathrm{kg}$ group was found to be significantly higher than in the control group. This may have been due to the lower body weight of the animals exposed to the highest NMP dose, compared to the controls (Table 1).

In the group of 44 female rats mated with 22 males exposed to NMP at $1000 \mathrm{mg} / \mathrm{kg}$, only 2 delivered live litter, and the total number of pups was 6 . The remaining females, although fertilized (sperms found in their vaginal smears) did not deliver live litter. Fertility assessment of the females mated with the exposed males did not reveal differences between the control and the 100 or $300 \mathrm{mg} / \mathrm{kg}$ groups. Female fertility, in terms of the number of pups in the litter, was also similar in those groups. However, the index of survival of the young animals in the $300 \mathrm{mg} / \mathrm{kg}$ group was significantly lower than in the controls. The maternal instinct of the females and the lactation process did not show any irregularities in the examined groups. The females nursed their pups, milk was found to be present in the stomachs of the pups, and body weight gain of the pups during the 4-week observation period was similar to that in the control group (Table 2).

Table 2. Effect of N-methyl-2-pyrrolidone on reproductive performance of male rats and viability of their progeny

\begin{tabular}{lcccc}
\hline \multirow{2}{*}{ Rats } & \multicolumn{5}{c}{ NMP dose (mg/kg b.w.) } \\
\cline { 2 - 5 } & 0 & 100 & 300 & 1000 \\
\hline $\begin{array}{l}\text { No. of females } \\
\text { mating with males }\end{array}$ & 23 & 24 & 24 & 44 \\
$\quad$ pregnant & 22 & 21 & 22 & 2 \\
$\quad$ No. of pups per litter & & & & \\
$\quad$ born alive & 11.5 & 11.5 & 12.8 & 3.0 \\
$\quad$ born dead & 0.18 & 0 & 0.14 & 0 \\
$\quad$ surviving to 4 days & 10.8 & 11.0 & 10.3 & n.o. \\
$\quad$ Indices: & & & & \\
$\quad$ fertility & 91.7 & 87.5 & 91.7 & $4.5^{\mathrm{a}}$ \\
viability $^{\mathrm{c}}$ & 94.0 & 95.9 & $80.9^{\mathrm{a}}$ & - \\
lactation $^{\mathrm{d}}$ & 96.1 & 100 & 98.0 & - \\
\hline
\end{tabular}

${ }^{a}$ significantly different $(\mathrm{p}<0.05)$ from the control values, ${ }^{\mathrm{b}} \%$ of pregnant females in mating females group,

c $\%$ of pups born alive that survived to 4 days, ${ }^{d} \%$ of pups alive at 4 days that survived to 21 days.

n.o. - not observed.
Table 3. Frequency of the developmental stages of seminiferous epithelium in the testis of rats exposed to N-methyl-2-pyrrolidone for 11 weeks

\begin{tabular}{lcccc}
\hline \multirow{2}{*}{$\begin{array}{c}\text { Daily dose } \\
\text { of NMP }\end{array}$} & $\begin{array}{c}\text { Number of } \\
\text { (mg/kg b.w.) }\end{array}$ & \multicolumn{3}{c}{ Stage of spermatogenesis } \\
\cline { 4 - 6 } animals & I-V & VI-VIII & IX-XIV \\
\hline 0 & 23 & $32.5 \pm 5.1$ & $28.1 \pm 5.7$ & $34.4 \pm 5.3$ \\
$100 \mathrm{mg} / \mathrm{kg}$ & 22 & $38.8 \pm 4.3$ & $25.8 \pm 5.3$ & $35.4 \pm 5.5$ \\
$300 \mathrm{mg} / \mathrm{kg}$ & 23 & $35.1 \pm 5.2$ & $24.8 \pm 6.1$ & $40.1 \pm 5.9$ \\
\hline
\end{tabular}

The values in the table represent the mean percentage of seminiferous epithelium cells at respective stages of spermatogenesis \pm SD.

The survival and lactation indices were calculated from the experimental data on the mothers and the pups. Among the offspring of the males exposed to NMP at $300 \mathrm{mg} / \mathrm{kg}$, the survival rate during the first four days postbirth was significantly lower than among the offspring of the control male rats (Table 2). The indices of the development of young animals, such as the age at which the pinna became detached, the lower incisors became erupted, and the lid slit became open, did not reveal significant differences between the offspring of the control males and of those exposed to NMP at 100 or $300 \mathrm{mg} / \mathrm{kg}$.

Table 3 displays the results of assessing the frequency of developmental stages of the seminiferous epithelium in the control rats and those exposed at 100 or $300 \mathrm{mg} / \mathrm{kg} /$ day.

Due to remarkable changes in the seminiferous epithelium in the gonads of male rats exposed to NMP at $1000 \mathrm{mg} / \mathrm{kg}$, it was impossible to assess the individual developmental stages of seminiferous epithelium in that group.

Stages I-V were noted in the groups of rats exposed to $\mathrm{NMP}$ at $100 \mathrm{mg} / \mathrm{kg}$ and $300 \mathrm{mg} / \mathrm{kg}$ in $38.8 \%$ and $35.1 \%$ of the tubules, respectively, and did not differ significantly from the findings for controls $(32.5 \%)$. Stages VI-VIII were slightly less frequent, $28.1 \%$ in the control, and $25.8 \%$ and $24.8 \%$ in the $100 \mathrm{mg} / \mathrm{kg}$ and $300 \mathrm{mg} / \mathrm{kg}$ groups, respectively. Stages IX-XIV could be seen in the groups exposed at $100 \mathrm{mg} / \mathrm{kg}, 300 \mathrm{mg} / \mathrm{kg}$, and in the controls at respective frequencies of $35.4 \%, 40.1 \%$ and $34.4 \%$. Note the relatively high values of standard deviation, indicating a considerable variation in the frequency of the stages of spermatogenesis in individual animals: variation coefficient 
higher than $10 \%$. Statistical analysis using Kruskal-Wallis test did not reveal significant differences in the frequency of individual stages of spermatogenesis between the 100 or $300 \mathrm{mg} / \mathrm{kg}$ group and the controls.

\section{Pathological changes within the seminiferous epithelium}

Tubule groups completely depleted of the seminiferous epithelium were found in 2 of the 23 rats exposed to NMP at $300 \mathrm{mg} / \mathrm{kg}$ (Fig. 2). Nevertheless, the process of spermatogenesis in those animals was not disturbed. Polynuclear, syncytial cells were not observed, and sperms were present in epididymal tubules. Interstitial oedema foci and intercellular oedema in the parabasal zone of the seminiferous epithelium were also found in 3 of 24 rats exposed to NMP at $300 \mathrm{mg} / \mathrm{kg}$ and in 2 of the animals exposed to the lower dose of $100 \mathrm{mg} / \mathrm{kg}$.

After 11 weeks' exposure of male rats to NMP at $1000 \mathrm{mg} / \mathrm{kg} /$ day, an extensive damage to the seminiferous epithelium of testicular tubules was noted (Fig. 3). Sertoli cells and few spermatogonia and spermatocytes were visible in the tubules close to the basement membrane (Fig. 4). It was interesting to note that neither early nor late spermatids could be found in the tubules. This finding points to an inhibition of the spermatocyte $\rightarrow$ spermatid stage of spermatogenesis. Few spermatozoa and spermiophages could be seen in the lumen of the epididymal tubules of those animals (Fig. 5).

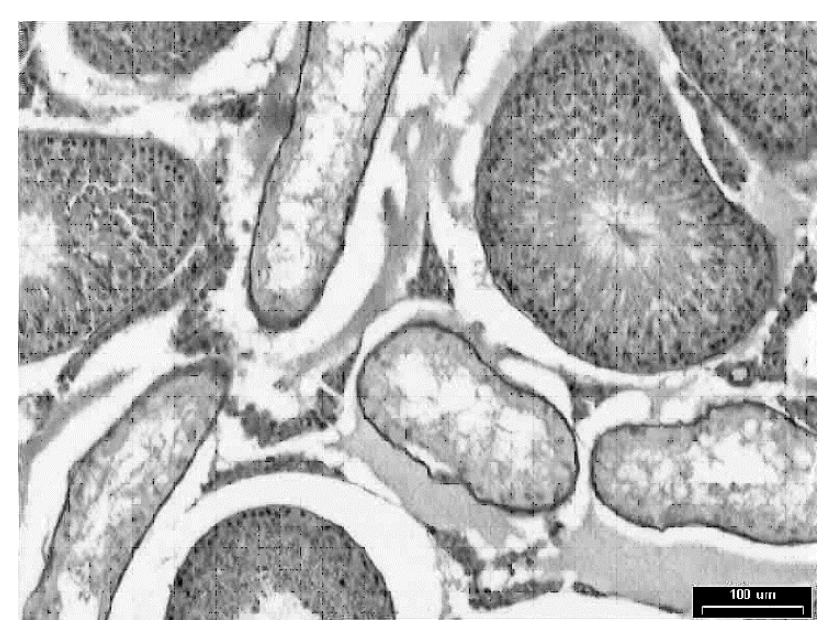

Fig. 2. Testis of a rat exposed to NMP at $300 \mathrm{mg} / \mathrm{kg} /$ day for 11 weeks. Note group of testicular tubules without seminiferous epithelium. PaS-hematoxilin staining.

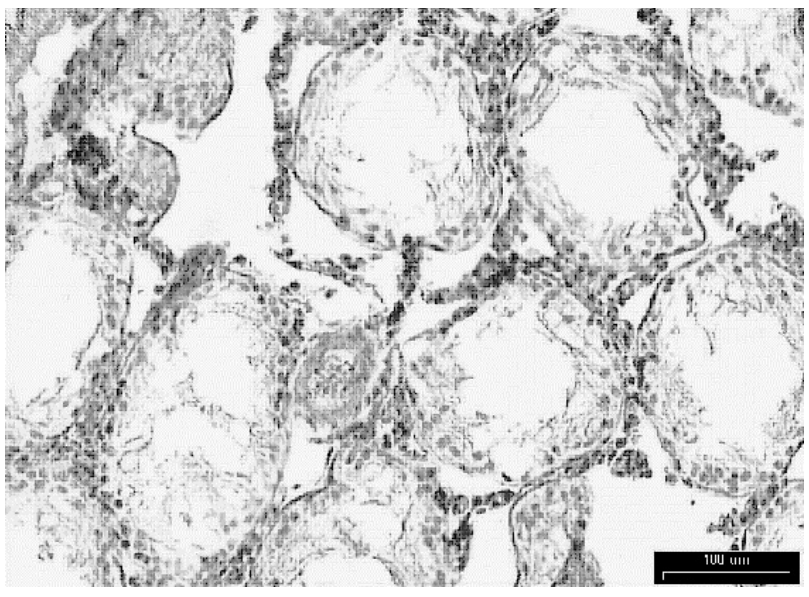

Fig. 3. Testis of a rat exposed to NMP at $1000 \mathrm{mg} / \mathrm{kg} /$ day for 11 weeks. Extensive damage (necrosis) of seminiferous epithelium. PaS-hematoxilin staining.

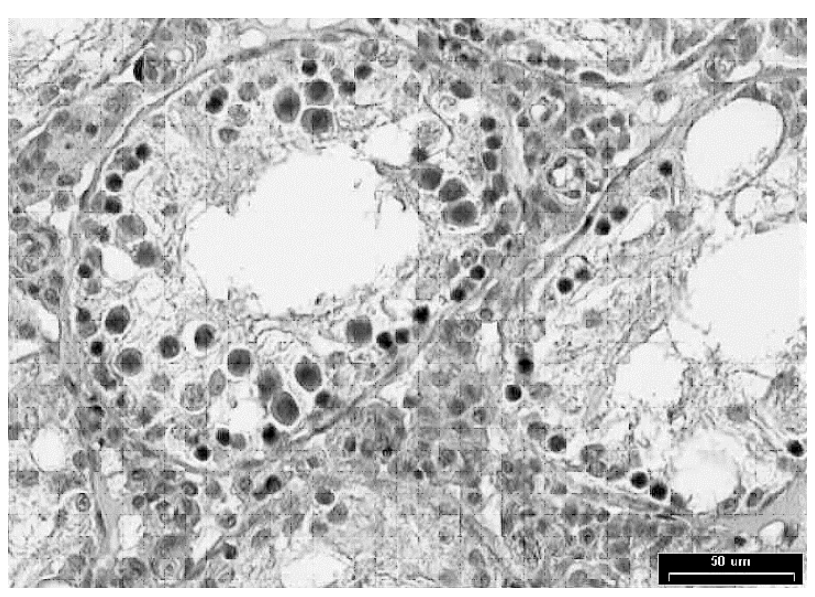

Fig. 4. Some spermatogonia and spermatocytes are seen in seminiferous tubules. PaS-hematoxilin staining.

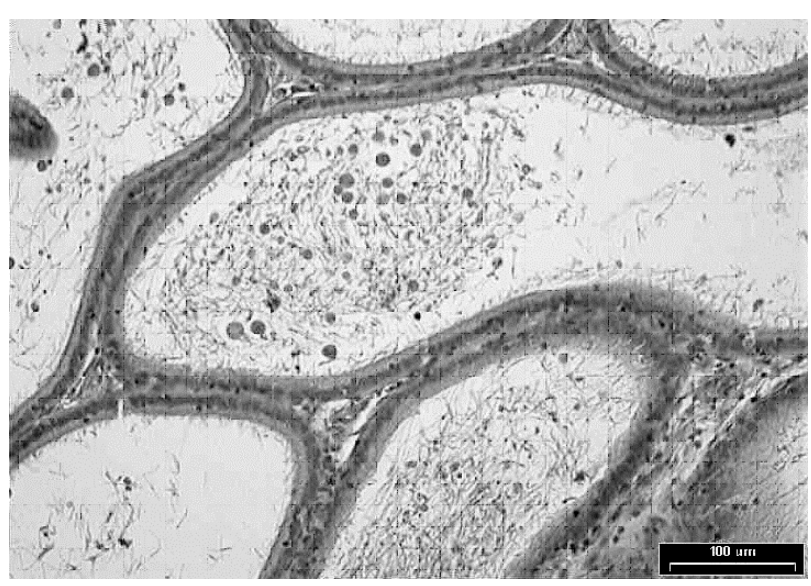

Fig. 5. Epididymis of a rat exposed to NMP at $1000 \mathrm{mg} / \mathrm{kg} / \mathrm{day}$ for 11 weeks. Some spermatids, spermatozoa and phagocytic cells (spermiophages) are seen in seminiferous tubuli. PaShematoxilin staining. 


\section{DISCUSSION}

Numerous authors report that N-methyl-2-pyrrolidone is a chemical which adversely affects reproduction and the development of the offspring of the exposed animals. In a two-generation study on NMP reproductive toxicity in rats exposed by inhalation to 41, 206 and $478 \mathrm{mg} / \mathrm{m}^{3} \mathrm{NMP}$ for 14 weeks, a somewhat lower mean body weight of the offspring of parents exposed to the highest dose was the sole observed effect of exposure [9].

Dermal exposure of rats at $1100 \mathrm{mg} / \mathrm{kg}$ b.w. during the period of organogenesis (gestation day 6 to 15) resulted in an evident embryotoxicity manifested by massive resorptions in the females. It should be noted, however, that this NMP dose was toxic to the pregnant females, causing a reduced body weight gain in pregnancy. At the same time, the lower dose of $240 \mathrm{mg} / \mathrm{kg}$ b.w. applied to the skin during organogenesis resulted in frequent fetal and embryonal resorptions, delayed ossification, and reduced maternal body weight gain in pregnancy [7]. Similar impairments of the prenatal development were observed in the offspring of female rats exposed by inhalation to NMP at $680 \mathrm{mg} / \mathrm{m}^{3}$ from gestation day 7 to 20 . Higher preimplantation losses were also noted in that study, but the number of implantations and of live fetuses in the litter from the control and exposed females did not differ significantly [15]. Neurobehavioral abnormalities and significantly lower body weight were noted in the offspring of female rats exposed to NMP at $622 \mathrm{mg} / \mathrm{m}^{3}$ from gestation day 7-20 [8]. In both the studies quoted above, NMP concentrations $\left(680 \mathrm{mg} / \mathrm{m}^{3}\right.$ and $622 \mathrm{mg} / \mathrm{m}^{3}$ ) were non-toxic to pregnant females, while they were detrimental to the offspring in spite of the relatively short period of exposure. NMP at the lower concentrations of $100 \mathrm{mg} / \mathrm{m}^{3}$ and $360 \mathrm{mg} / \mathrm{m}^{3}$ did not impair the prenatal development of the offspring of female rats exposed by inhalation during organogenesis. Temporary breathing disturbances and coma were observed only in the mothers at the onset of exposure to the higher of NMP concentrations [6].

Developmental toxicity of N-methyl-2-pyrrolidone was also assessed in the study by Saillenfait et al. [16], in which female rats were exposed by gavage to NMP at doses ranging from $125 \mathrm{mg} / \mathrm{kg}$ to $750 \mathrm{mg} / \mathrm{kg}$ on gestation day 6-20. At the two higher doses of $500 \mathrm{mg} / \mathrm{kg}$ and $750 \mathrm{mg} / \mathrm{kg}$, NMP showed a toxic effect on the mothers, as well as embryotoxicity, fetotoxicity and teratogenicity, inducing such malformations as an incompletely open anal orifice, absence of tail, malformed major blood vessels, and delayed ossification. The authors underline that the developmental toxicity occurred even when no maternal toxicity could be observed.

In our study, N-methyl-2-pyrrolidone appeared to be toxic to the reproductive system of male rats. The chemical administered per os to male rats at $1000 \mathrm{mg} / \mathrm{kg} /$ day for 11 weeks made them infertile. The pathomorphological examination of the testis and epididymis removed on the day of dissection revealed very serious abnormalities, including extensive damage to the seminiferous epithelium. Inhibition of spermatogenesis was noted at the level of transition from spermatocyte to spermatid in the seminiferous tubules. Spermiophages and only few spermatozoa were found in epididymal tubules. The lower NMP doses of $300 \mathrm{mg} / \mathrm{kg} / \mathrm{day}$ and $100 \mathrm{mg} / \mathrm{kg} /$ day did not impair male fertility. Pathomorphological assessment of the gonads in rats of the 100 and $300 \mathrm{mg} / \mathrm{kg}$ groups did not reveal any irregularities of spermatogenesis in the seminiferous epithelium, and the frequency of individual phases of epithelial maturation was similar to that of the control rats. NMP exposure at $100 \mathrm{mg} / \mathrm{kg}$ did not significantly impair male fertility or spermatogenesis. Neither did it affect the viability or the development of their offspring during the first month of their life. The group exposed to $300 \mathrm{mg} / \mathrm{kg}$ was found to have a significantly lower viability of the offspring during the first four days of life.

The results of the pathomorphological assessment of seminiferous epithelium in male rats from the group exposed to $1000 \mathrm{mgNMP} / \mathrm{kg}$ are consistent with our previous findings - relatively high ${ }^{14} \mathrm{C}$ concentrations of 1.28 and $1.33 \mathrm{kBq} / \mathrm{g}$ tissue in the testis and seminal vesicles, respectively, were observed $4 \mathrm{~h}$ after a single intraperitoneal administration of ${ }^{14} \mathrm{C}-\mathrm{NMP}$ [17].

Numerous cases of infertility and serious testicular damage visible under light microscopy were detected in rats exposed to the highest dose of $1000 \mathrm{mg} / \mathrm{kg}$. The ability to accumulate NMP and/or its metabolites in the testis and 
seminal vesicles may account for the impaired male fertility observed in this study after repeated exposure to this chemical.

\section{ACKNOWLEDGEMENTS}

The authors express their appreciation to Zdzisława Pisarek, Urszula Dądziak and Dr. Aleksander Krajnow for their contribution to this project.

\section{REFERENCES}

1. Akesson B, Carmerup MA, Jönsson BAG. Evaluation of exposure biomarkers from percutaneous absorption of $N$-methyl-2-pyrrolidone. Scand J Work Environ Health 2004;30(4):306-12

2. Ursin C, Hansen CM, Van Dyk JW, Jensen PO, Christensen IJ, Ebbehoej J. Permeability of commercial solvents through living human skin. Am Ind Hyg Assoc J 1995;56:651-60

3. Payan JP, Boudry I, Beydon D, Farby JP, Grandclaude MC. Toxicokinetics and metabolism of N-[14C]N-Methyl-2-pyrrolidone in male Sprague-Dawley rats: in vivo and in vitro percutaneous absorption. Am Soc Pharmacol Exp Therap 2003;31:659-69

4. Ansell JM, Fowler JA. The acute oral toxicity and primary ocular and dermal irritation of selected $\mathrm{N}$-alkyl-2-pyrrolidones. Food Chem Toxicol 1988;26:475-9

5. Bartsch W, Sponer G, Dietmann K, Fuchs G. Acute toxicity of various solvents in the mouse and rat. Arzneimittel-forschung 1976;26:1581-3

6. Lee KP, Chromey NC, Culik R, Barnes JR. Toxicity of N-methyl-2-pyrrolidone (NMP): teratogenic, subchronic, and two-year inhalation studies. Fundam Appl Toxicol 1987;9:222-35

7. Becci PJ, Knickerbocker MJ, Reagan EL, Parent RA, Burnette LW. Teratogenicity study of N-methylpyrrolidone after dermal application to Sprague-Dawley rats. Fundam Appl Toxicol 1982;2:73-76

8. Hass U, Lund S, Elsner J. Effects of prenatal exposure to Nmethylpyrrolidone on postnatal development and behavior in rats. Neurotoxicol Teratol 1994;16:241-9

9. Solomon HM, Burgess BA, Kennedy GL Jr., Staples RE. 1-Methyl-2-pyrrolidone (NMP): reproductive and developmental toxicity study by inhalation in the rat. Drug Chem. Toxicol 1995;18 (4):271-93

10. Clemont Y, Perry B. The stages of the cycle of the seminoferous epithelium of the rat: practical differences in PA ShiffHematoxylin and hematoxylin-eosin stained sections. Rev Can Biol 1957;61:451-61

11. Hess RA. Qualitative and quantitative characteristics of the stages and transitions in the cycle of the rat seminiferous epithelium. Light microscopic observations of perfusion-fixed and plastic-embedded testes. Biol Reprod 1990;43:525-42

12. Hess A, Moore BJ. Histological methods for evaluation of the testis. In: Methods in Toxicology vol. 3a. San Diego: Academic Press Inc.;1993. p. 52-85

13. Zar JH. Biostatistical Analysis. New York: Englewood Cliffs, Prentice-Hall; 1974

14. Fisher LD, van Belle G. Biostatistics. A Methodology for the health sciences. New York: John Wiley and Sons; 1993

15. Hass U, Lund SP, Elsner J. Developmental toxicity of inhaled N-methylpyrrolidone in the rat. Neurotoxicol Teratol 1995;16:241-9

16. Saillenfait AM, Gallissot F, Langonne I, Sabate JP. Developmental toxicity of N-methyl-2-pyrrolidone administered orally to rats. Food Chem Toxicol 2002;40:1705-12

17. Sitarek K, Kilanowicz A. Tissue distribution and excretion of $\mathrm{N}$-methyl-2-pyrrolidone in male and female rats. Int. J. Occup. Med Environ Health 2006;19(2):142-8 